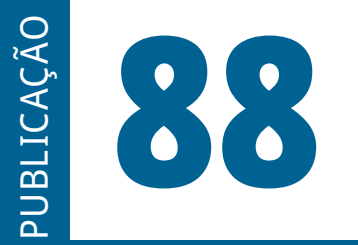

ISSN: 0101-9562

ISSN ELETRÔNICO: 2177-7055

SEQÜÊNCIA

Publicação do

Estudos jurídicos

e políticos

Programa de Pós-Graduação em Direito da UFSC

VOLUME 42 - ANO 2021 
SEQUÊNCIA - ESTUDOS JURÍDICOS E POLÍTICOS é uma publicação temática e de periodicidade quadrimestral, editada pelo Programa de Pós-Graduação Stricto Sensu em Direito da Universidade Federal de Santa Catarina - UFSC.

SEQUÊNCIA - ESTUDOS JURÍDICOS E POLÍTICOS is a thematic publication, printed every four months, edited by the Program in law of the Federal University of Santa Catarina - UFSC.

Versão eletrônica: http://www.periodicos.ufsc.br/index.php/sequencia

A publicação é indexada nas seguintes bases de dados e diretórios/

The Publication is indexed in the following databases and directories:

Base OJS

Base PKP

CCN (Catálogo Coletivo Nacional)

Dialnet

DOAJ (Directory of Open Access Journals)

EBSCOhost

Genamics Journalseek

ICAP (Indexação Compartilhada de Artigos de Periódicos)

Latindex

LivRe!

OJS
PKP
Portal de Periódicos UFSC
Portal do SEER
ProQuest
SciELO
Sherpa/Romeo
Sumarios.org
ULRICH'S
vLex

Ficha catalográfica

Seqüência: Estudos jurídicos e políticos. Universidade Federal de Santa Catarina.

Programa de Pós-Graduação em Direito. n.1 (janeiro 1980)-.

Florianópolis: Fundação José Boiteux. 1980-.

Publicação contínua

Resumo em português e inglês

Versão impressa ISSN 0101-9562

Versão on-line ISSN 2177-7055

1. Ciência jurídica. 2. Teoria política. 3. Filosoia do direito. 4. Periódicos.

I. Universidade Federal de Santa Catarina. Programa de Pós-graduação em

Direito

CDU 34(05)

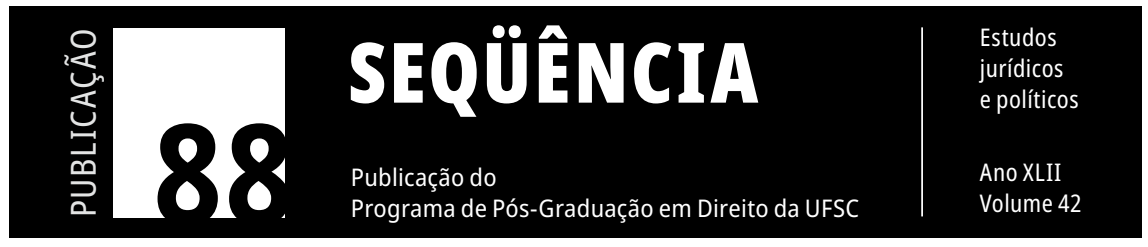




\title{
The contribution of tax expenditure in fiscal consolidation in post-crisis economies: a case study of the context in Portugal ${ }^{1}$
}

\section{A contribuição das despesas fiscais na consolidação orçamentária em economias pós-crise: um estudo de caso do contexto em Portugal}

\author{
João Ricardo Catarino \\ Universidade de Lisboa, Lisboa, Portugal \\ Rui Miguel Alcario Salvador \\ Universidade de Lisboa, Lisboa, Portugal \\ Ricardo de Moraes e Soares \\ Universidade de Lisboa, Lisboa, Portugal
}

ABSTRACT: In this research, we analyse the use of fiscal expenditure as an instrument of fiscal consolidation policy. Portugal was subject to the financial assistance programme (PAEF) articulated with the IMF, the European Commission and the European Central Bank between 2010 and 2014. The objective is to analyse the evolution of fiscal expenditure in the following four years, after the end of that term programme, that is, between 2015-2018. The outcome is to know if the policy of reducing fiscal expenditure implemented in the years in which the programme was in force (2010-2014), continued into the following four years. We compared this evolution with the evolution of direct expenditure, based on two main axes: economic expenditure and social expenditure. The data collection technique is used through document research, and the data obtained was from information provided by national, European statistical authorities and secondary sources of information. It is concluded that, in the 2014-2018 period, the increase in public revenue, due

This work is financed by national funds through the FCT - Foundation for Science and Technology, I.P., under project UIDP/00713/2020. 
to the decrease in tax expenditure, did not evolve consistently. In 2014-2018, direct public expenditure did not follow the same pattern as in the previous years of 2011-2014, given the functional equivalence of the two types of expenditure. Finally, to observe the relationship between the level of fiscal consolidation, carried out between the years 2010 and 2018, and the behaviour of tax revenue and expenditure, the Scheffé test was performed on the averages of the variables Total Revenue and Expenditure, and Tax Revenue and Expenditure. This was applied in order to observe if the averages of the variables are significantly relevant for the level of fiscal consolidation or if there are other variables, equally important, that were not taken into account in the study, but that had a preponderant role (such as the economic context). We have to statistically conclude that both the revenue and expenditure averages and the percentage averages are not all equal, as they are, in fact, all different between the groups analysed.

In order to clarify if the differences in revenue and expenditure and in the respective percentages are statistically significant or if, on the contrary, they are merely eventual, we previously verified their applicability through the assumptions of normality and homoscedasticity of each of the data sets, using the ANOVA test (Fisher, 1918). We observed that for both the amounts of revenue and expenditure, as well as the percentages, the p-value observed in the ANOVA test was equal to 0.000 (i.e. less than 0.050), implying the rejection of the null hypotheses and the acceptance of the alternative hypotheses, according to which the average values of the amounts of revenue and expenditure, and the average values of the percentages are not all equal. The general conclusion is that there was budget consolidation, but this must have been due to other factors, such as the economic environment, since there is no direct relationship between revenue, fiscal expenditure and budget consolidation in any of the periods studied.

KEYWORDS: Budgetary consolidation - Debt crisis - Debt - Expenditure - Fiscal Expenditure - Public finances.

RESUMO: Nesta pesquisa analisamos o uso do gasto fiscal como um instrumento de política de consolidação orçamentária. Portugal esteve sujeito ao programa de assistência financeira (PAEF) articulado com o FMI, a Comissão Européia e o Banco Central Europeu entre 2010 e 2014. O objetivo é analisar se a evolução dos gastos fiscais nos quatro anos seguintes, após o término desse programa de assistência (2015 e 2018) manteve o mesmo padrão que se verificou no período de assistência financeira externa. Procuramos saber se a política de redução dos gastos fiscais, implementada nos anos em que o programa esteve em vigor (2010-2014), teve continuidade nos quatro anos seguintes. Comparamos esta evolução com a evolução dos gastos orçamentários diretos, com base em dois eixos principais: os gastos econômicos e os gastos sociais. Conclui-se que, no período 2014-2018, o aumento da receita pública por efeito da diminuição da despesa fiscal, não evoluiu de forma consistente. Em 2014-2018, os gastos públicos diretos não seguiram o 
mesmo padrão que nos anos anteriores de 2011-2014, dada a equivalência funcional dos dois tipos de gastos. A despesa fiscal desceu nos anos de 2011 e 2012, e subiu nos anos de 2012 e 2013. A despesa geral do Estado diminui até 2012, depois aumentou nos anos seguintes, mas num grau muito menor do que a despesa fiscal. Os dados evidenciam que entre 2010 e 2012, se verificou um decréscimo tanto na despesa fiscal (20\%) quanto na despesa direta (11,6\%) do Estado, tendência que se inverteu em 2013 com o crescimento de ambas (45,4\% e 8,4\%, respetivamente). Já no período 2014 a 2016 se verifica o crescimento da despesa fiscal (3,3\%) e a diminuição da despesa direta.

Para observar a relação entre o nível de consolidação fiscal, realizada entre os anos de 2010 a 2018 e o comportamento das receitas e despesas fiscais, foi realizado o teste de Scheffé às médias das variáveis Receita e Despesa Total, e Receita e Despesa Fiscal. Este teste permite-nos concluir estatisticamente que tanto as médias da receita e despesa como as médias das percentagens não são todas iguais, como são, efetivamente, todas diferentes entre os grupos analisados. Tendo em visa esclarecer se as diferenças na receita e despesa e nas respetivas percentagens são estatisticamente significativas ou se, ao invés, são meramente eventuais verificamos ainda, previamente, a sua aplicabilidade por intermédio dos pressupostos de normalidade e homocedasticidade de cada um dos conjuntos de dados, recorrendo ao teste ANOVA. O observamos que quer para os montantes de receita e despesa, quer para as percentagens, o p-valor observado no teste ANOVA foi igual a 0,000 (isto é, inferior a 0,050), implicando a rejeição das hipóteses nulas e a aceitação das hipóteses alternativas, segundo as quais os valores médios dos montantes de receita e despesa, e os valores médios das percentagens não são todos iguais. Concluímos que houve consolidação orçamentária, mas esta deve ter-se ficado a dever a outros fatores, tais como a conjuntura económica, já que não se verifica uma relação direta entre a receita, a despesa fiscal e a consolidação orçamentária em nenhum dos períodos estudados.

PalaVRAS-Chave: Consolidação orçamentária - Crise da dívida - Dívida - Despesa - Despesa fiscal - Finanças públicas.

\section{INTRODUCTION}

Between 2007 and 2014, Europe suffered a severe financial crisis that originated in the so-called sovereign debt crisis. The countries of southern Europe suffered the greatest impact. In Portugal, the rapid deterioration of budget deficits, the need for more financing to respond to the high indebtedness of the public and private sectors, 
and the low rates of economic growth showed the high dependence on external financing that resulted in distrust of economic agents and the financial system in the sustainability of fiscal policies (OECD, 2010, 2011, 2013a, 2013b).

As a consequence, the financing of State, families, and companies were aggravated, which caused a notable increase in the cost of public debt. Without autonomous countercyclical monetary policy mechanisms, the Portuguese government had to ask the European Union (EU) for financial assistance, which culminated, on May 17, 2011, in the signing of the Memorandum of Understanding on Economic Policy Conditionalities (MoU) (provided for in the "budgetary treaty") (OECD, 2014).

The Economic and Financial Assistance Programme (PAEF) lasted 36 months and ended on May 17, 2014, without the need for any additional external financial assistance. The objective was to recover competitiveness and put the Portuguese economy on a growth path, reinforce the stability of the financial system, and carry out a process of adjustment to the Portuguese public finances to achieve greater solidity (Economic and Financial Assistance Programme (PAEF), 2011, p. 12).

The Portuguese fiscal consolidation, in the period 2011-2014, was pursued through several instruments that acted both on the side of revenue and on public expenditure, as is often the case (Beetsma, Cimadono, Fortuna, \& Guiliodori, 2015; Sunley, 2004). In this sense, on the one hand, we seek to analyse how Portugal proceeded with the consolidation of public accounts. It is an option followed or recommended in several studies (Afonso \& Jalles, 2012; Afonso, Arcanjo, Pereira, \& Santos, 2012; Howard, 1995; OECD, 1996). On the other hand, the study aims to assess the extent to which fiscal consolidation was achieved through one of the available instruments, i.e., tax expenditure, namely: (i) whether it contributed to revenue growth and (ii) whether it evolved in the same measure of direct expenditure (Devries, Guajardo, Leigh, \& Pescatori, 2011; Ende, Haberham, Amir, \& Boogert, 2004; OECD, 2010). 
The restrictive measures adopted in the course of the budgetary consolidation process, within the scope of the PAEF, resulted in the reduction of the budget deficit, which led to a decrease in public expenditure and an increase in tax revenue and public revenue. In this sense, fiscal expenditure was an essential fiscal policy instrument that, inserted in a broader fiscal consolidation strategy, acted on the revenue side and contributed to its growth (Martins, 2004; McDaniel \& Surrey, 1985). However, during the Economic and Financial Assistance Programme (PAEF), fiscal expenditure and direct expenditure followed the same behaviour, although the former varied more intensely, as a result of their nature and functional equivalence. Therefore, their joint analysis facilitates a more appropriate intervention by the State in the economy and society.

This research aims to analyse the behaviour of fiscal expenditure in the period between 2014 and 2018, and observe whether the expenditure trajectory remained in the following four years. The interest in the research results from the fact that, in the years since the Economic and Financial Assistance Programme (PAEF), Portugal is no longer under the obligations assumed in the Assistance Plan and is a free country to decide how to manage its activities, their finances, and, above all, their fiscal public policies. (Kraan, 2004; Nakamura \& Singleton, 2016).

As one of the most relevant instruments of State action refers to public policies, the object of analysis thereof is not only the observation of political power in action, but also the use of political power as an institutional instrument for obtaining public revenues. Among them, fiscal policies stand out (FERreIra, 2011) as increasing economic development (GArcia, 2002). For Nohlen (2008) without defining the concept, it is not possible to reach a result, so we believe that it is important to clarify the concept of public fiscal policy. And, the task is not simple, because the term "public policy" is subject to semantic and meaning difficulties (Hughes, 1994).

Fiscal policy can be defined as that by which, through the use of taxes and other financial instruments, including public expenditure and 
revenue, the economy, the distribution of the tax burden, consumption, disposable income, and assets are influenced, aiming at the more harmonious development of the society in general and the structural stability and sustainability of public accounts (CATARInO \& FOnSECA, 2013; Poterba, 2011). Naturally, a fiscal policy is influenced by the different types of actors, public and private, politicians and bureaucrats, citizens and companies, national and international, who intend, in an organized way, to produce and execute the institutional preferences capable of increasing their benefit and of settling the financing and public spending strains (Knoepfel, Larrue, Varone, \& Hill, 2007). In this sense, fiscal policy can be defined in different ways, which, at first glance, may seem like a theoretical redundancy, as all political decisions are, by their nature, public (European Commission, 2007). Even so, it is possible to indicate the following definitions of public policies, adapted to the widely considered fiscal area:

(i) Public fiscal policies are all the decisions that governments either want or do not want in the framework for the activity of collecting revenue and public spending (DyE, 1972);

(ii) Public fiscal policy is the consequence of the activity of an institutional body invested with public power and legitimacy (MÉNY \& Thoenig, 1989);

(iii) Public policies are a set of fiscal programmes specific to certain areas or sectors of society (MÉny \& Thoenig, 1989);

(iv) Public policies form a set of organizational activities, including fiscal ones, aimed at altering society's actions, within a framework defined by mandated public institutions (MÉNy \& Thoenig, 1989);

(v) Public fiscal policies are the result of a set of activities aimed at obtaining revenue and spending by political actors whose relations are organized (LEMIEUX, 1995);

(vi) They are a group of decisions, aimed at collecting revenue and realizing fiscal expenditure (SAraiva, 2006);

(vii) A set of public decisions aimed at fiscal actions to maintain or change the reality of one or more sectors, through the elaboration 
of strategies and allocation of the necessary means to achieve the established objectives (SAraiva, 2006);

(viii) They are a set of actions and fiscal decisions of political actors to obtain income and expenses (CALDAs, 2008);

(ix) They are the totality of actions, goals, and plans that governments outline to obtain a higher level of tax revenue (CALDAs, 2008);

(x) These are fiscal options that, among many, involve political conflict in which the final product is the aggregate of several options that pass through the sieve of objectivity (Melazzo, 2010);

(xi) Public fiscal policies reflect the context of their production, execution and the social, economic, and political context in which they occur (FADigas, 2015);

(vii) They portray the fiscal actions of political and public actors, aimed at obtaining revenues to satisfy public needs (BILHim, 2016).

Although the notions are different, they tend to emphasize the idea of actors invested with public power, and in the building of solutions by political actors through public policies (LAsswell \& KAPLAN, 1950). For Muller (1990), the definition of public policy must be associated with an operational perspective, essential to qualify the object of study and the research field of the analysis, which is also verified in relation to fiscal policies. Among the instruments of tax policy are the exclusions, exemptions, tax or rate reductions, tax suspensions, deductions from collection or taxable matter, as well as tax and financial benefits or incentives (Gomes, 1991; Aramayo, 1997; Catarino and Teixeira, 2016; Molnar, 2012). In this research we will study the behaviour of two of these instruments, namely: the tax expense and the tax benefits granted by the State in the period considered (BRIXI \& Valenduc, 2004; Ende, Haberham, \& Boogert, 2004).

The concept of fiscal expenditure was portrayed by the OECD (1996, pp. 9-10) as an exercise between the provisions of the tax laws that are part of the rule-taxation regime and those that depart from it (Catarino, 2020; Cabral \& Martins, 2014). In this sense, among others, the taxation-rule regime contains the rate structure, the deductibility 
of mandatory payments, and the provisions related to internal and international tax obligations (CATARINO, 2017). Kraan (2004, p. 130), in turn, defines it as a transfer of public resources achieved through the reduction of tax obligations in relation to the tax regime of reference, instead of a direct expenditure.

The OECD (2010, pp. 12-14), characterizes public expenditure according to the following typology:

(i) Deductions. The amount subtracted in order to reach the taxable base;

(ii) Exemptions. The amount waived from the tax obligation;

(iii) Fee/Preferred rates. The rate reduction applied to a group of taxpayers or taxable transactions;

(iv) Deferral of taxation. This results in a postponement of tax payment;

(v) Tax credits. The amount to be deducted against a tax liability.

In Portugal, the concept of tax expense is directly related to the concept of tax benefit, insofar as the Statute of Tax Benefits (EBF) considers it tax expenses (EBF, 2000, paragraph 3 of article 2). These are constitutionally enshrined in the Portuguese constitution (CRP, 1976, [2005], paragraph g) of paragraph 3 of article 106) and are defined as "measures of an exceptional nature instituted to protect relevant extra-fiscal public interests that are superior to those of taxation that they prevent." (EBF, 2000 , no. 1 of article 2). The loss of revenue resulting from the concession of tax benefits is treated by the financial laws as outgoing revenue and classified as tax expense (budgetary framework law (LEO), 2013, paragraph 4 of article 8; points t) and v) of paragraph 1 of article 37).

Ferreira (1989, p. 31) stated that the concept of tax expenditure has no definition expressed in the Portuguese legal system, although it has been affirmed at the international level. The absence in the national legislation of precise formal specification of the concept was noted by the OECD (1996, p. 87), although it mentioned that, in practice, the tax and customs administration adopted an operational concept of tax expenditure. Due to the absence of a precise formal concept, 
some grey areas result in the classification of certain tax provisions as tax expense or as part of the rule-tax structure. According to Gomes (1991, p. 318) it is a "loss of tax revenue resulting from the existence of exceptional tax benefits, related to situations subject to taxation, and which are equivalent to direct cash subsidies". In economic terms, it is "a virtual expenditure of resources originally belonging to the State" (MARTINs, 2004, p. 25), while, in legal terms, it is considered an estimate in relation to the "waiver of tax revenues, which would be collected by the State according to the content of the taxation-rule." (MarTins, 2004, p. 90), and whose cause is the tax benefits. Thus, "they do not correspond to any inflow of cash flows since the resources originally belonging to the State are not collected at all" (Martins, 2004, p. 93; Eurostat, 2013).

The State Budget (OE) and the General State Account (CGE) estimate the outgoing revenue related to the attribution of tax benefits, since only these can result in the quantification of tax expenditure (CRP, 1976, [2005], article $106 \mathrm{n}^{\mathrm{o}}$ 3; LEO, 2013, points t) and v) of paragraph 1 of article 37 ) from a financial perspective (which takes place in the year in which the tax is paid). The other reliefs, enshrined in tax rules, must be classified as structural reliefs and do not contribute to tax expenditure, although they can be quantified (Gomes, 1991, p. 16).

\section{METHODOLOGY}

The research methodology was based on the collection of data through documentary research. The data was obtained from information provided by national and European statistical authorities and secondary sources of information. The analysis will focus on a case study research design (Yin, 2009; Carmo \& Ferreira, 2008). According to Yin (2009), case studies are very useful to analyse the regularity of a given social phenomenon. To this end, the general objective of this study is to analyse the behaviour of tax expenditure in the period following the end of the financial assistance programme (2014/2018) applied to Portugal. The aim 
is to know whether the trajectory of this expenditure has remained stable or not over the three years following the end of financial assistance, and also to compare this evolution with that of direct expenditure, based on two main axes: economic expenditure and social expenditure (BRYMAN, 2004; BeLl, 2004). The data was mainly collected in the State Budget $(\mathrm{OE})$, in the General State Account (CGE), and in the Fiscal Expense Report (RDF) available on the official page of the Directorate-General for Budget (DGO), the Government Portal, and in National Statistics Institute (INE) for the years covered by this research.

Finally, a Scheffé test was carried out on the means of the variables under analysis in order to understand the degree of relationship between the level of fiscal consolidation, carried out between the years 2010 and 2018, and the behaviour of tax revenue and expenditure.

\section{RESULTS AND DISCUSSION}

This research covers the years 2014 to 2018. The period corresponds to the first four-year period in which Portugal ceased to be subject to the rules and objectives of the PAEF. However, even so, the evolution of Portuguese public finances continued to raise concerns about that plan, namely, the continuation of an adjustment effort translated into the progressive reduction of the budget deficit through the implementation of measures, mainly within the framework of the state budget (Ministério DAS FinanÇAs, 1998, 2005, 2012, 2013, 2014, 2016, 2017; MFAP, 2011).

For the period 2011 to 2014 , contrary to what was initially foreseen, it appears that part of the measures on the expenditure side were replaced by increases of a fiscal nature (tax increases), which guaranteed the fulfilment of the budgetary consolidation objective (Ministry OF FInANCES, 2015, p. 26), although this option has a greater negative impact in terms of confidence in the consolidation process (BEETSMA et al., 2015, p. 444). Thus, there was a need to change the profile of 
the expected adjustment effort with the implementation of additional measures with greater weight on the revenue side, specifically between the years 2011 and 2013. For the Court of Auditors (TdC), the reduction in the balance between 2010 and 2014 (4,418 thousand euros) was due exclusively to the increase in public revenues (Tribunal de Contas, 2015, pp. 153-155), a trend that was reversed, since in 2016 there was a greater contribution from expenditure ( $€ 3,319$ thousand) than revenue ( $€ 700$ thousand) for the reduction of the nominal deficit (Conselho de Finanças Públicas, 2017, p. 4; BdP, 2009; TdC, 2012, 2014).

In Portugal, in the period from 2014 to 2018, there was a tendency to reduce the budget deficit of Public Administrations (excluding financial assets and liabilities), from $7.2 \%$ to $0.4 \%$ of GDP, which allowed for the obtaining of the conditions necessary to exit the excessive deficit procedure. The budgetary consolidation effort can be obtained by increasing revenue and/or reducing expenditure, individually or in combination; and it was observed that, in terms of public revenue, growth in this period was $13.6 \%$ ( $€ 10,483$ thousand), as shown in Graph 1. However, it is important to emphasise that the collection of tax revenue also had a growth trajectory (19.5\%), which continues to represent the biggest source of income of the State (59, 3\% of total revenue collected).

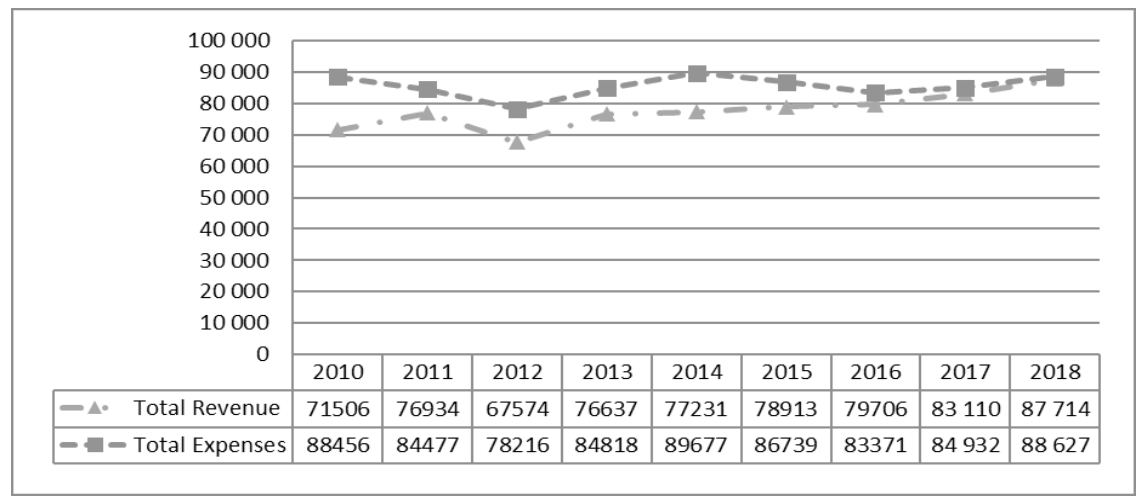

Graphic 1 - Evolution of revenue and public expenditure ( $\mathrm{m} €$ )

Source: General State Account and State Budget (CGE and OE) data.

Self-elaboration. 


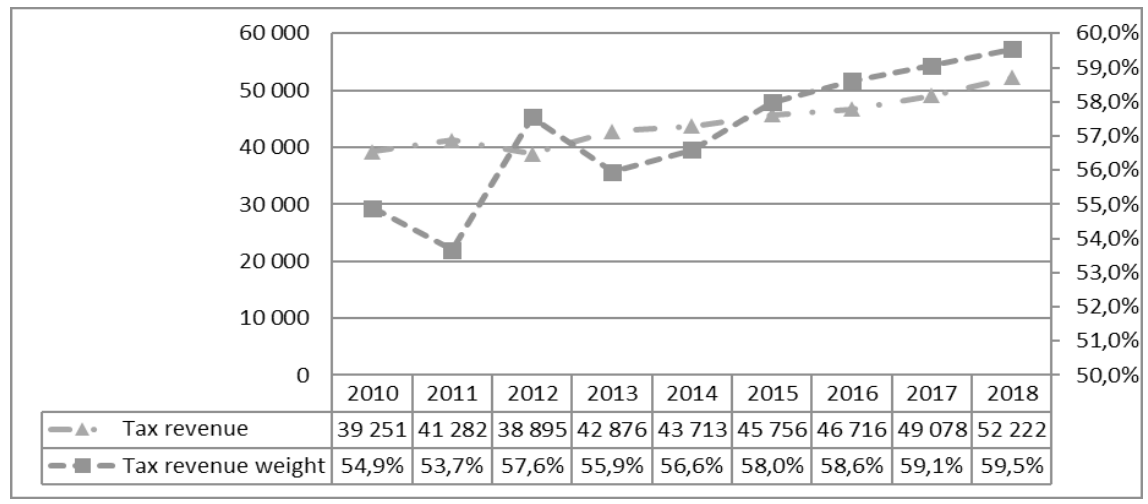

Graphic 2 - Evolution of tax revenue $(m €)$

Source: General State Account and State Budget (CGE and OE) data.

Self-elaboration.

In 2012, there was no revenue growth (a trend observed for the remaining years), but a decrease of $12.2 \%$ was verified, due to the negative behaviour of fiscal revenue of personal income tax (IRS) and corporate income tax (IRC) - a decrease of $7.6 \%$ and $17.2 \%$ of revenue respectively. The biggest increase was $13.4 \%$ in 2013 , driven by the positive behaviour of tax revenue, an increase of $13.3 \%$, as a result of the tax increase (for both IRS and IRC, there was an increase in revenue of $35,5 \%$ and $19 \%$, respectively), with a direct effect on budgetary consolidation. This was achieved through a greater variation of structural revenue in relation to structural primary expenditure, to which the measures introduced in the respective State Budget contributed, as well as the adoption of extraordinary measures (namely the Exceptional Regime Debt Settlement (TdC, 2014, p. 66). In the remaining years, there was an increase in tax revenue and public revenue, highlighting the better behaviour of indirect taxes to the detriment of direct taxes. For instance, in the year 2016 the slight improvement in public revenue $(0.9 \%)$ was sustained by the increase in tax revenue by $1.4 \%$, with a greater expression of indirect taxes $(3.9 \%)$, as a result of the evolution of activity, economic and employment, and 
the implementation of the Special State Debt Reduction Programme (MF, 2017, p. 12). The revenue growth in this period contributed to the improvement in the expense coverage ratio (expressed to what extent the revenue collected covers the expense), from $80.8 \%$ in 2010 to $86.1 \%$ in 2014 and from $98.9 \%$ for 2018 .

The reduction in the budget deficit, supported by the increase in revenue, between 2014 and 2018, resulted in an increase in the level of taxation from $34.3 \%$ of GDP to $35.4 \%$ of GDP, which represents an increase of $1.1 \mathrm{pp}$. The growth is uniform and more significant when compared to the average level of taxation of $31.6 \%$ of GDP presented in the period from 2000 to 2009 (Eurostat, 2013, p. 172). In the variation from 2015 to 2016, a decrease of $0.3 \mathrm{pp}$ in the level of taxation is underlined, contrary to the trend of the last three years. In the period 2017 to 2018 the main contributions were the increase in tax revenue (0.7 pp of GDP) and contributory revenue (0.2 pp) justified by the evolution of economic activity and the labour market, in a context of reduced rates for various taxes; the decrease in interest charges (0.4 pp); and the decrease in personnel expenses, social benefits, and intermediate consumption (0.3 pp).

As for the budgetary consolidation effort, on the side of public expenditure, as shown in Graph 1, it can be seen that from 2014 to 2018 the adjustment made was based on a downward trend, with a decrease in expenditure of $1.2 \%$ ( $€ 1,050$ thousand). In the period between 2010 and 2012, we observed that the largest contribution to the budgetary consolidation effort came from the reduction of current expenditure, with emphasis on the reduction of personnel expenses, as a result of the adoption of measures to reduce wages and restrictions on promotion and progression applied to public sector workers, as well as capital expenditures, as an effect of the decrease in public investment. We also observed that this trend was not perceived in 2013 and 2014, where there was an increase in direct expenditure of 8.4\% (CGE, 2013, p. 102) and 5.7\% respectively. In 2015, the trend was reversed, supported by the reduction of the item "Other capital 
expenditures", where "most of the one-off and temporary measures and special factors" were verified (MF, 2015, p. 17) and, where, in 2016, there was a 0.9 pp reduction in GDP (MF, 2017, p. 11).

The analysis of the evolution of expenditure in the sub-sectors of central public administration from 2014 to 2018, when analysed by the budgetary classification of government functions (COFOG), shown in Graph 3, shows a decrease in total expenditure.

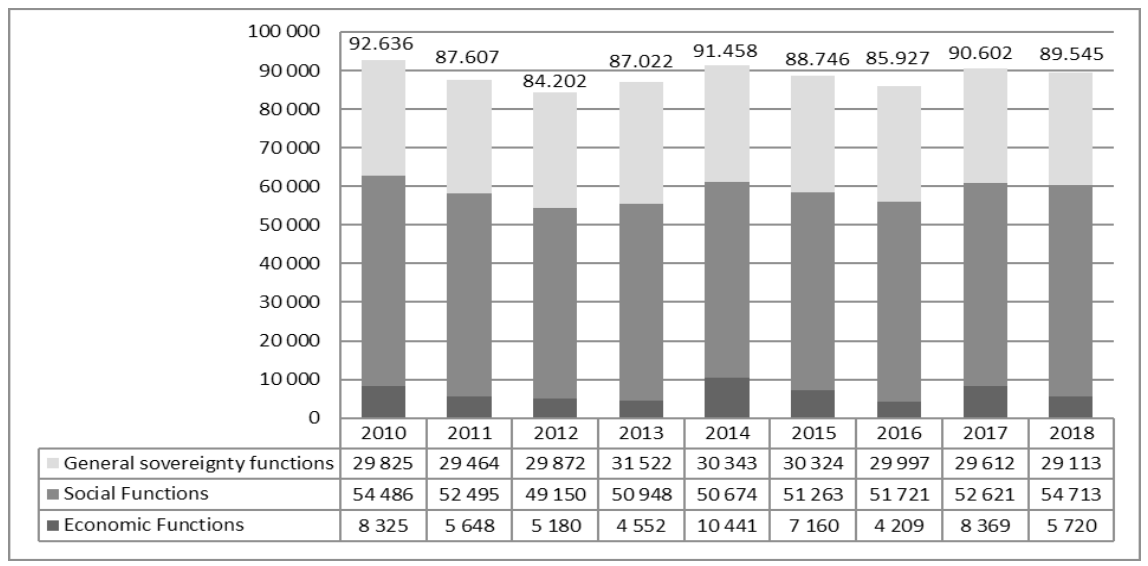

Graphic 3 - Total public expenditure by function - COFOG and Integrated services; autonomous services and funds and social security (SI, SFA and SS) ( $m €$ )

Source: Data from the National Institute of Statistics. Self-elaboration.

The data shows a $31.3 \%$ increase in public expenditure associated with economic functions ( $€ 2,605$ thousand) and a $0.4 \%$ decrease in social functions ( $€ 227$ thousand). These trends were also determined by the increase in the relative weight of economic functions in direct expenditure from $6.4 \%$ in 2010 to $8 \%$ in 2015, being less noticeable in social functions, where relative weight decreased from $60.3 \%$ to $58.9 \%$ in the same period. 


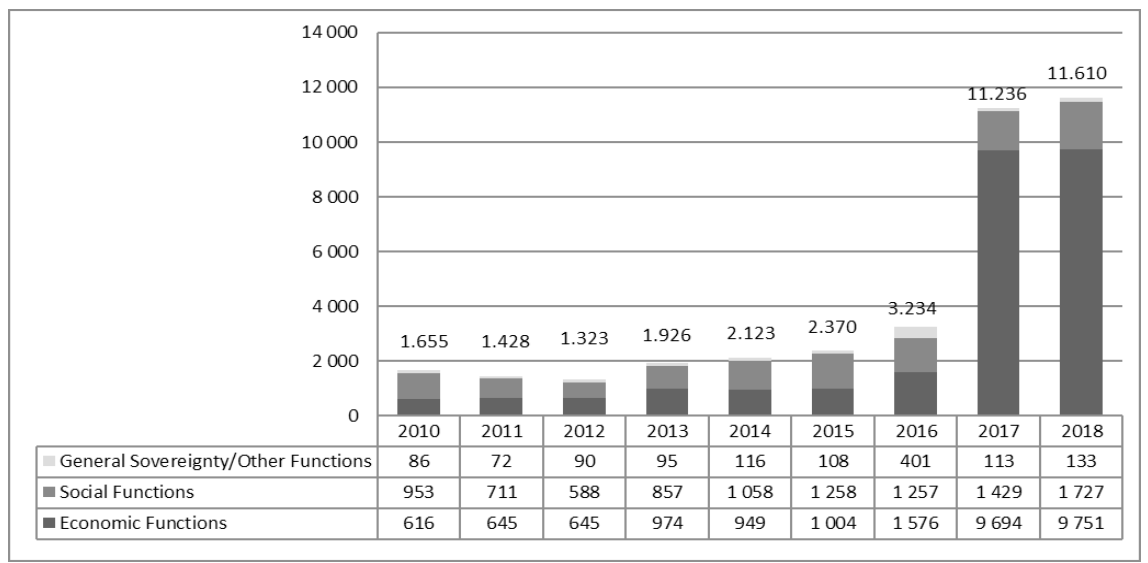

Graphic 4 - State tax expenditure (integrated services (SI) and social security (SS) by function

Source: General state account (CGE) data. Self-elaboration.

Tax expense, by State function, showed a decrease of $20.0 \%$ (€ 332 thousand) between 2010 and 2012, obtained through the limitation of tax benefits (Catarino \& Teixeira, 2016, p. 734). This trend did not continue as shown in Graph 4, as there was an increase of $389.9 \%$ ( $€ 9,241$ thousand) between 2012 and 2018.

It can be seen from Graph 4 that fiscal expenditure on social functions showed an increasing trend of 63.3\% between 2014 and 2018, although registering a decrease of 10.1\% ( $€ 96$ thousand) between 2010 and 2013. Economic functions, on the other hand, show a strong growth of $927.4 \%$ in the same period. The increase in tax expenditure, verified from 2013 to 2015, is explained by the recording, for the first time, of unreported expenditure, which contributed to increased transparency, but also hindered comparability of information (MF, 2013, p. 74). In its assessment of the year 2013, the Portuguese Court of Accounts (TdC) underlined the importance of these recordings, as follows: when "taking into account the impact of these factors [report], the tax expenditure quantified by the AT did not increase" (TdC, 2014, p. 191). These trends were also observed by 
the growth of the relative weight of the State's economic functions, which increased from $50.6 \%$ in 2014 to $84.0 \%$ in 2018, in contrast to the relative weight of social functions in fiscal expenditure, which decreased from $49.8 \%$ to $14.9 \%$ in the same period. It should be noted that fiscal expenditure depends to a large extent on economic activity: strong growth normally leads to higher revenues, which, in turn, lead to more exemptions and, consequently, higher costs of fiscal expenditure (Howard, 1995, p. 439).

The tax expense quantification process in 2017 underwent a significant change, since it now complies with the criteria set out in the Tax Expense Quantification Manual prepared by the Portuguese Tax Administration (AT). This Manual was used for the first time in 2017 for the quantification of tax expenses in the State Budget. Under the terms of the Manual, the attenuations resulting from taxation with preferential rates have become part of the concept of tax expenditure with the result that the registered changes take on greater relevance in terms of VAT and Vehicle Tax, resulting in an overall increase of $316 \%$ in fiscal expenses in 2017 compared to the previous year, which affects the exercise of comparability that year (CGE, 2017).

In compliance with the provisions of the Economic and Financial Assistance Programme (PAEF), the Tax Expense Report was prepared, which included as "fiscal expense", the "provisions of the tax law, regulations or practices that constitute a reduction or deferral of the tax due by a specific group of taxable persons, in relation to the system of taxation-rule" (MF, 2014, p. 11). This option gave rise to an understanding in the strict sense of the taxation-rule system, which implied that many tax provisions reflect situations that do not result solely from the attribution of tax benefits. As such, they were not considered as tax expense in the State Budget and State General Account, but were treated as tax expense creating a more comprehensive tax regime. Under Personal income tax (IRS), this is demonstrated by the following inclusions: deductions from the collection of health expenses, charges for real estate and homes, as well as personal deductions from taxpayers, their 
dependents and their descendants, and, in the case of VAT, the reduced and intermediate rates.

Between 2010 and 2012, as shown in Graph 5, the State's fiscal expenditure by function decreased by $48 \%$ ( $€ 6,962$ thousand), as a result of the "current policy of reviewing tax benefits, in compliance with the international commitments assumed by the Portuguese State under the PAEF" (MF, 2014, p. 6). This trend was not followed in subsequent years, as shown by an increase of $19.1 \%$ ( $€ 1,459$ thousand) between 2012 and 2015 (MF, 2016, p. 74).

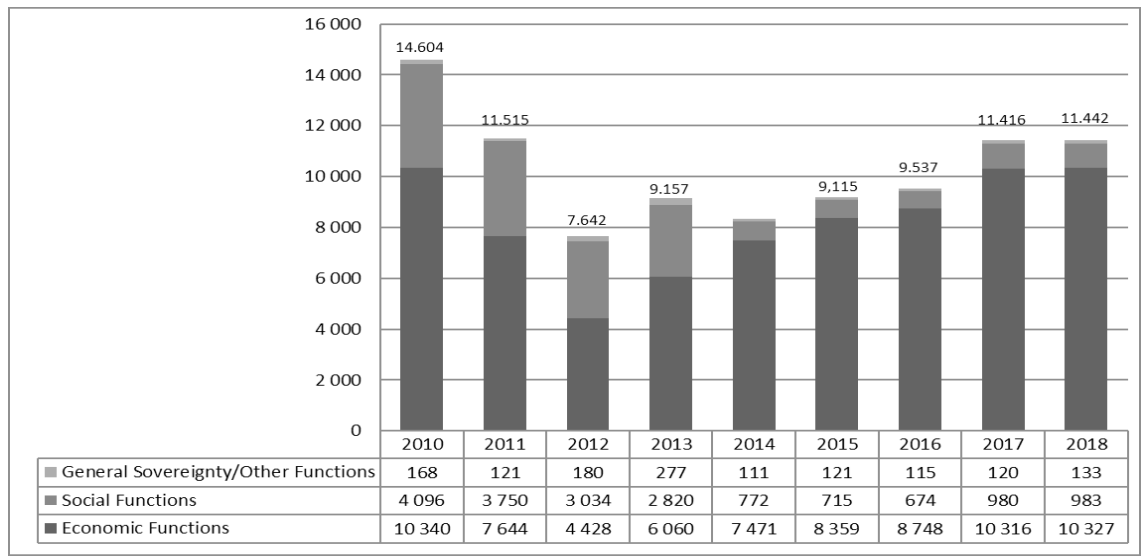

Graphic 5 - State tax expenditure by function (Tax expenditure report) (€ $\mathrm{m}$ ) Source: Tax Expense Report. Self-elaboration.

The data in Graph 5 shows that fiscal expenses associated with economic functions decreased by $27.7 \%$ (2010 to 2014) and increased between 2015 to 2018 (in the order of 90.0\%). Tax expenses related to social functions decreased by $21.0 \%$ (2010 to 2018). The latter is explained by the need to safeguard fiscal expenditure associated with social functions in order to minimise the impact of fiscal consolidation on the most vulnerable population groups. In social functions, there is a decrease less than that which occurred with total tax expenditure, in contrast to what happened with fiscal expenditure associated with economic functions (MF, 2014, p. 7). 
In the 2010-2014 period, the reduction in deductions considered a tax expense in the personal income tax (IRS) resulted in a $12 \%$ decrease in expenses ( $€ 43$ thousand). In 2016, there was an increase of $1.9 \%$ in expenses ( $€ 7$ thousand), which indicates a reversal of trend in recent years. With regard to structural relief, we observe that, in the period 2010 to 2014, some deductions in personal income tax (IRS) registered a reduction of $27 \%$ ( $€ 900$ thousand). The modifications made to the reduced and intermediate VAT rates reveal a decrease of $34 \%$ ( $€ 1,741$ thousand). If an extended period to 2018 is considered, the data reveals an equal trend, with a decrease of $33.1 \%$ of total expenses ( $€ 1,096$ thousand).

In the case of VAT, the increase in general, intermediate and reduced rates from $21 \%$ to $23 \%$, from $12 \%$ to $13 \%$ and from $5 \%$ to $6 \%$, as well as the subjection to the general rate of several goods and services that were previously subject to the reduced and intermediate rates, implied that many goods and services started to be taxed at the normal tax rate. The difference between the application of reduced and intermediate rates and VAT due to the State in the case of application of the standard rate was considered in the tax expense report (MF, 2014, p 36; Ende, Haberham, \& Boogert, 2004, p. 136). However, for 2016 and for the purposes of the State budget (OE) in terms of VAT, there were changes in the classification of tax provisions and in their quantification as tax expense, namely the reduced rate and the intermediate rate of that $\operatorname{tax}$ (estimated at $€ 4,169$ thousand). It should be noted that the Tax Expenditure Reports for 2015, 2016 and 2017 were not released, so the recommendation that the Government proceed to the annual elaboration of a detailed tax expenditure report was not fulfilled (European UniOn, 2012, p. 58; 2012a; 2012b; 2012c).

The substitute nature of tax benefits in relation to direct expenditure and the possibility of configuring proper subsidies or cash subsidies for the beneficiary and the tax creditor (Gomes, 1991, p. 97) make it possible to integrate the estimate of tax expenditure in the calculation of State effective expenditure. The integrated data makes 
it possible to optimize the combination of fiscal expenditure and direct expenditure by functional area within the scope of budgetary choices and contribute to improving the taxpayers' perception of the degree of State intervention (economy and society) (Graph 6 illustrates this integration).

Graph 6 shows that in 2015 the State allocated a total of $€ 53,639$ thousand to social functions, distributed by $€ 52,381$ thousand (98\%) in direct expenditure, in $€ 1,258(2 \%)$ in tax expenditure, and a total of $€$ thousand 8,147 to economic functions, of which there was $€ 7,143$ thousand (88\%) in direct expenditure and $€ 1,004$ (12\%) in tax expenditure. We emphasize the greater relative weight of fiscal expenditure in economic functions, which has always increased between 2010 and 2013 (9\%, 10\%, 12\% and 17\%, respectively), decreasing in 2014 (8\%), and growing again in the following year (2015) (12\%). Fiscal expenditure in social functions remained constant (between $1 \%$ and $2 \%$ ).

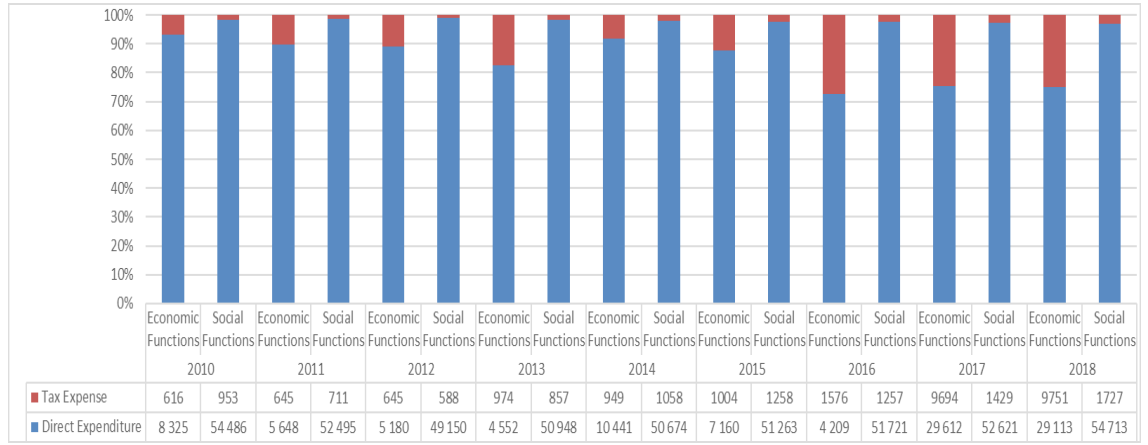

Graphic 6 - Integration of tax and direct expenditure by function

Source: Data from Statistics national institute (INE) and State general account (CGE). Self-elaboration.

The relationship between the variation of tax expenditure and public revenue in the period 2010 to 2018 evolved in the opposite direction, with regard to the fiscal expense report (DF), but maintained the same behaviour with regard to the DF highlighted in the 
general state account (CGE) including integrated public services and social security, as shown in graph 7 .

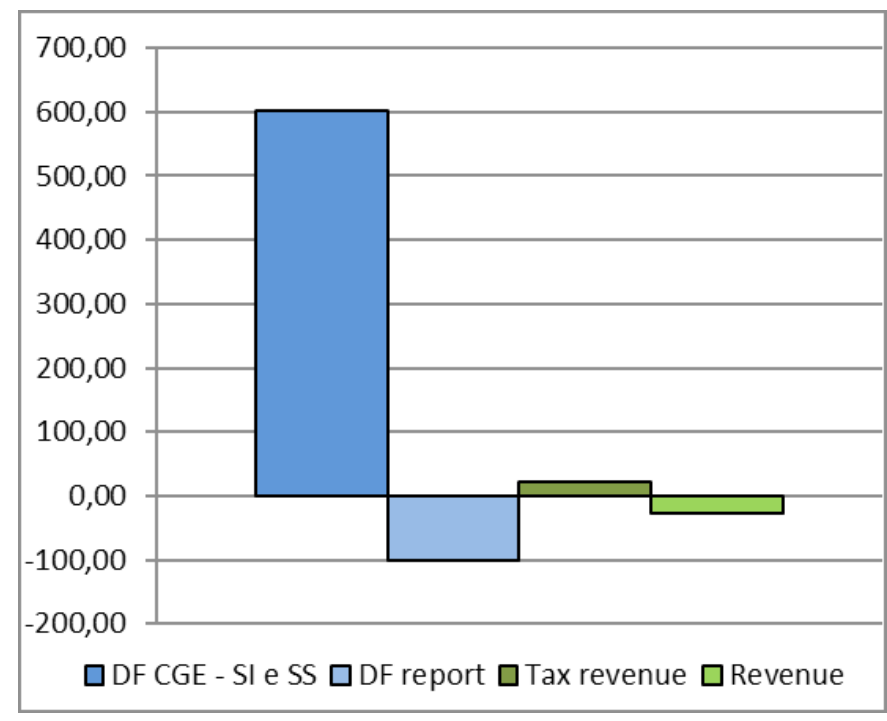

Graphic 7 - Evolution of fiscal expenditure versus public revenue (\% variation 2010-2018)

Source: Data from State general account (CGE), Fiscal Expenditure Report and National statistics institute (INE). Self-elaboration.

As shown in Graph 7, the decrease in tax expenditure with the consequent growth in tax revenue occurred only at the beginning of the Economic and Financial Assistance Programme (PAEF), more specifically during the period 2010-2012. In this period the tax expense report considered, for this purpose, structural reliefs, in particular the deductions from the personal income tax (IRS) collection and the reduced and intermediate VAT rates.

It should be noted that the growth of the fiscal expenditure is not subject to any quantitative limit, as it varies according to the behaviour of the beneficiaries and economic activity, without prejudice for the need to estimate the revenue (MF, 2015, p. 72). The relationship between the annual variation in fiscal expenditure and 
direct expenditure in the years 2010 to 2013, which encompassed the Economic and Financial Assistance Programme (PAEF) period, evolved in the same direction, despite the smaller range of variation of the latter, as shown in graph 8. However, in the period 2013-2016, in just 2 years, the tax expense reported in the general state account (CGE) evolved in the same direction as direct expenditure (Graphic 6).

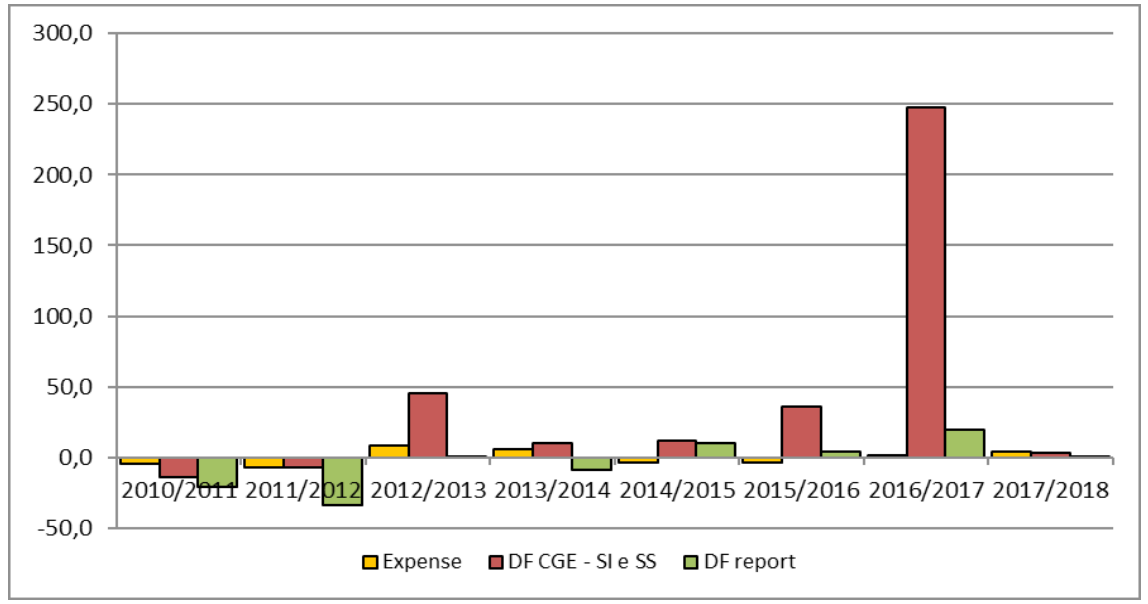

Graphic 8 - Evolution of fiscal expenditure versus expenditure (annual variation) (\%) Source: Data from State general account (CGE) and the Fiscal Expenditure Report 2014. Self-elaboration.

The linear correlation coefficient ( $r$ ) expresses the direction and intensity of the linear relationship between two variables. In graph 8 , we compare the evolution of direct expenditure with fiscal expenditure in the years 2010 to 2018. As evidenced, direct expenditure (reported in the CGE, SI and SS) and the fiscal expense presented in the Tax Expense Report show a variation in the same direction and with approximate levels, of $[\mathrm{r}=0.52]$ and $[\mathrm{r}=0.45]))$, respectively. The relationship between the r-squared model between the general state account, integrated services, and social security (CGE, SI and SS) of [r2 $=0.27]$ and the Tax Expense Report of [r2=0.36]) presents a low variance. 


\section{STATISTICAL ANALYSIS}

To observe the relationship between the level of fiscal consolidation, carried out between the years 2010 to 2018, and the behaviour of tax revenue and expenditure, the Scheffé test was performed on the averages of the variables Total Revenue and Expenditure, and Tax Revenue and Expenditure. This was applied in order to observe if the averages of the variables are significantly relevant for the level of fiscal consolidation or if there are other variables, equally important, that were not taken into account in the study, but that had a preponderant role (such as the economic context).

This raises the question of whether the differences in revenue and expenditure and their respective percentages are statistically significant or whether, on the contrary, they are merely contingent. To this end, we previously verified its applicability through the assumptions of normality and homoscedasticity of each of the data sets, using the ANOVA test (Fisher, 1918). Table 1 shows that for both the amounts of revenue and expenditure and the percentages, the p-value in the ANOVA test was 0.000 (i.e. less than 0.050), implying the rejection of the null hypothesis and the acceptance of the alternative hypothesis that the mean values of revenue and expenditure and the mean values of the percentages are not all equal.

Table 1 - Results of the ANOVA Test

\begin{tabular}{|c|c|c|c|c|c|c|}
\hline \multicolumn{2}{|l|}{ Description } & $\begin{array}{l}\text { Sum of the } \\
\text { Squares }\end{array}$ & $\begin{array}{l}\text { Degrees } \\
\text { of freedom }\end{array}$ & $\begin{array}{c}\text { Mean Squares } \\
\text { Statistic }\end{array}$ & F Significance & Significance \\
\hline \multirow{3}{*}{$\begin{array}{l}\text { Total } \\
\text { Revenue and } \\
\text { Expenditure }\end{array}$} & $\begin{array}{l}\text { Inter- } \\
\text { groups }\end{array}$ & 37286334750 & 3 & 12428778250 & 589,54 & 0,000 \\
\hline & $\begin{array}{l}\text { Intra- } \\
\text { groups }\end{array}$ & 674623634 & 3 & 21081988 & --- & --- \\
\hline & Total & 37960958384 & 35 & --- & --- & --- \\
\hline \multirow{3}{*}{$\begin{array}{l}\text { Tax } \\
\text { Revenue and } \\
\text { Expenditure } \\
\text { (\%) }\end{array}$} & $\begin{array}{l}\text { Inter- } \\
\text { groups }\end{array}$ & 1 & 1 & 1 & 916,58 & 0,000 \\
\hline & $\begin{array}{l}\text { Intra- } \\
\text { groups }\end{array}$ & 0 & 16 & 0 & --- & --- \\
\hline & Total & 1 & 17 & --- & --- & --- \\
\hline
\end{tabular}

Source: Self Elaboration. 
We have also applied the Scheffé test. This test allows us to statistically conclude that the averages of income and expenditure and the averages of the percentages are not all equal, but are in fact all different between the groups analysed (Table 2).

Table 2 - Scheffé test

\begin{tabular}{|c|c|c|c|c|c|}
\hline \multirow{2}{*}{ Description } & \multirow{2}{*}{$\begin{array}{l}\text { Sample } \\
\text { size }\end{array}$} & \multicolumn{3}{|c|}{ To alpha $=0,05$} & \multirow{2}{*}{$\begin{array}{l}\text { Critical } \\
\text { Value of } \\
\text { Scheffé }\end{array}$} \\
\hline & & Group & Subgroup & Result & \\
\hline \multirow{3}{*}{ Total Revenue } & 9 & Total Revenue & Tax Revenue & 472,872 & \multirow{12}{*}{8,703} \\
\hline & 9 & Total Revenue & Total Expenditure & 25,816 & \\
\hline & 9 & Total Revenue & Tax Expenditure & 2321,073 & \\
\hline \multirow{3}{*}{ Total Expenditure } & 9 & $\begin{array}{c}\text { Total } \\
\text { Expenditure }\end{array}$ & Total Revenue & 25,816 & \\
\hline & 9 & $\begin{array}{c}\text { Total } \\
\text { Expenditure } \\
\end{array}$ & Tax Revenue & 719,666 & \\
\hline & 9 & $\begin{array}{c}\text { Total } \\
\text { Expenditure }\end{array}$ & Tax Expenditure & 2836,466 & \\
\hline \multirow{3}{*}{ Tax Revenue } & 9 & Tax Revenue & Total Revenue & 472,872 & \\
\hline & 9 & Tax Revenue & Total Expenditure & 719,666 & \\
\hline & 9 & Tax Revenue & Tax Expenditure & 698,645 & \\
\hline \multirow{3}{*}{ Tax Expenditure } & 9 & $\begin{array}{c}\text { Tax } \\
\text { Expenditure } \\
\end{array}$ & Total Revenue & 2321,073 & \\
\hline & 9 & $\begin{array}{c}\text { Tax } \\
\text { Expenditure }\end{array}$ & Tax Revenue & 698,645 & \\
\hline & 9 & $\begin{array}{c}\text { Tax } \\
\text { Expenditure }\end{array}$ & Total Expenditure & 2836,466 & \\
\hline & 9 & $\begin{array}{c}\text { Tax Revenue } \\
(\%)\end{array}$ & $\begin{array}{c}\text { Tax Expenditure } \\
(\%)\end{array}$ & 1833,162 & \multirow[b]{2}{*}{4,494} \\
\hline & 9 & $\begin{array}{c}\text { Tax } \\
\text { Expenditure } \\
(\%)\end{array}$ & Tax Revenue (\%) & 1833,162 & \\
\hline
\end{tabular}

Source: Self elaboration.

As can be seen in Table 2, the statistical results suggest that for all groups and sub-groups the mean contrasts are higher than the result of the Scheffé critical value for an alpha of $5.0 \%$. This means, for all the results obtained, that there are statistically significant differences between the means. Thus, it is not possible to conclude that the 
positive behaviour of fiscal consolidation, between 2010 and 2018, is the exclusive result of the evolution of total revenue and expenditure and of tax revenue and expenditure.

\section{CONCLUSIONS}

Within the scope of the Economic and Financial Assistance Programme (PAEF) (2011-2014), Portugal had to carry out a fiscal consolidation process to ensure the convergence of the structural budget balance and achieve a sustainable trajectory for public finances, supported both on the revenue side and on the expenditure side.

The importance of fiscal expenditure, as an instrument that could influence revenue, was recognized within the scope of the Economic and Financial Assistance Programme (PAEF) in the first reports published by the IMF and the EU. The preparation of an annual tax expense report and the definition of a clear methodology were considered as structural tax measures for the estimation of tax expense, according to the best international practices (IMF, 2012a, p. 94).

Among the measures taken by Member States to pursue the goal of reducing the debt-to-GDP ratio, there is the increase in efficiency and control of public spending and the review of fiscal expenditure (European Commission, 2015, p. 14).

During the Economic and Financial Assistance Programme (PAEF) the Portuguese Government presented two documents that showed different results in terms of the quantification of tax expenditure, due to the use of divergent classification and quantification criteria, which shows difficulties in aligning and using the concepts. But since the General State Account is the accountability document that includes the financial information (revenues and expenses) on the execution of the state budget, it was through the Fiscal Expense Report (which does not integrate the legally defined budget process), 
that the information on the evolution of fiscal expenditure within the scope of the PAEF was analysed. This makes it the benchmark in decision-making on the measures to be implemented within the scope of public policies in the course of the budgetary adjustment process. However, it is important to underline that, after the Economic and Financial Assistance Programme had ended, the government ceased to prepare the annual tax expenditure reports to which it had been linked.

The growing recognition of the use of the fiscal expenditure factor as an important instrument in a context of budgetary consolidation has contributed to the improvement and extension of reporting, review, and control procedures, in line with developments in the OECD (2010, p. 15). In this context, the Portuguese Tax Authority, in response to a recommendation from the Court of Auditors of Portugal (2014, p. 40), prepared a manual for the quantification of tax expenditure. As of 2016, tax expenditure on the reduced and intermediate VAT rate started to be quantified.

In this research, the data suggests that the restrictive measures adopted in the course of the budgetary consolidation process, whether within the scope of the Economic and Financial Assistance Programme (PAEF), or later, resulted in a real reduction of the budget deficit. It appears that, in the first years, especially in 2013, this reduction was achieved at the expense of the growth in tax revenue and public revenue rather than the decrease in public expenditure. This trend was also seen in terms of the composition of the fiscal adjustment effort carried out in the euro area between 2011 and 2014.

As for the initial question, whether tax expenditure contributed to the growth of public revenue (and that being an estimate regarding the waiver of tax revenues that would be collected by the State) (Gomes, 1991, p. 25), we conclude that it decreased, contributing to the increase in public revenue and to the budgetary consolidation process (MARTINS, 2004, p. 151).

We conclude that the need to increase public revenue implied the waiver of tax benefits and other structural reliefs, which highlights the 
importance of tax expenditure in assessing the budgetary adjustment process during the Economic and Financial Assistance Programme (PAEF) in 2011-2014 and in 2014-2018. The reduction of expenditure through the limitation and elimination of tax benefits has also helped to reduce the complexity and reduce the economic inefficiency of the Portuguese tax system.

However, in the period from 2010 to 2018, the relationship between the increase in public revenue due to the decrease in tax expenses was not consistently confirmed. In the year 2016, there was an increase in tax revenue. But this was a year of recovery in economic activity and the progressive improvement of conditions in the labour market (MF, 2017, p. 11).

Thus, it is concluded that tax expenditure, which is not subject to any quantitative limit, cannot be the main explanatory variable of the behaviour of public revenue, namely, that reported by general state account (CGE) for which it still adds its small relative weight in tax revenue (which ranged from $3.7 \%$ in 2011 to $5.7 \%$ in 2016).

However, the evidence suggests that the reduction of fiscal expenditure was an important fiscal policy instrument, which, inserted in a broad fiscal consolidation strategy, had a positive effect on the side of public revenue, contributing also to its growth.

Tax expenditure and direct public expenditure share a functional equivalence (McDaniel \& Surrey, 1985, p. 3), which allows us to conclude that, during the Economic and Financial Assistance Programme (PAEF), both showed a tendency to follow the same behavioural pattern. Fiscal expenditure varied more intensely, although, after this period, this trend was no longer present.

The data shows that between 2010 and 2012, there was a decrease both in fiscal expenditure (20\%) and in direct expenditure (11.6\%) of the State. This trend was reversed in 2013 with the growth of both ratios (45.4\% and 8.4\%, respectively). In the period of 2014 to 2016, there was an increase in fiscal expenditure (3.3\%) and a decrease in direct expenditure (7\%), a trend also evidenced in the report of fiscal 
expenditure. The growth in tax expenditure in recent years is mainly explained by the inclusion of several taxes, as a consequence of the need for greater scrutiny and greater transparency to which this expense was subjected in this period, which denotes its underestimation in previous years (IMF, 2007, 2012a, 2012b).

From the perspective of the functions of the State, we also conclude that between 2010 and 2013 direct expenditure registered a greater decrease in economic functions (20.3\%) than in social State functions $(7.3 \%)$. The tax expense report shows that the decrease associated with economic functions (41.4\%) was higher than that seen in social functions $(31.2 \%)$, due to the need to minimize the impact of budgetary consolidation on the most vulnerable groups of citizens (MF, 2014, p. 7). This pattern is not seen in the fiscal expenditure of the State. This expense, despite having grown globally, registered, in that period, an increase associated with economic functions (58.1\%) while decreasing in social functions (10.1\%).

In the period from 2013 to 2015, direct expenditure registered a higher increase in economic functions (51.1\%), much higher than that seen in social functions (1.3\%), contrary to what was registered in the tax expense report, which shows a higher increase associated with social functions (18.7\%) than with economic functions (1.7\%), and in the fiscal expenditure of the State, also with a higher increase associated with social functions (46.8\%) than in economic functions (3.1\%).

It is possible to conclude that, due to the functional equivalence of fiscal expenditure and direct expenditure, their integration in the Fiscal Expenditure Report provides a more complete picture of the scope and weight of State intervention in the economy and in society. This aggregated perspective of the two types of expenditure thus contributes to a greater visibility and better perception of the State's action in terms of expenditure, either by taxpayers or by political actors, responsible for the formulation of public policies (NAKAmura \& Singleton, 2016, p. 56). This integrated view contributes to improving the transparency of information, reducing the effect of tax 
illusion on the taxpayer, and promoting a rigorous application and management of public resources, namely, regarding the comparison of the effectiveness between both expenses and the optimization of their combination within the scope of budgetary choices.

Finally, to observe the relationship between the level of fiscal consolidation, carried out between the years 2010 and 2018, and the behaviour of tax revenue and expenditure, the Scheffé test was performed on the averages of the variables Total Revenue and Expenditure, and Tax Revenue and Expenditure. This was applied in order to observe if the averages of the variables are significantly relevant for the level of fiscal consolidation or if there are other variables, equally important, that were not taken into account in the study, but that had a preponderant role (such as the economic context). This test allows us to statistically conclude that both the revenue and expenditure averages and the percentage averages are not all equal, but are in fact all different across the groups analysed.

In order to clarify if the differences in revenue and expenditure and in the respective percentages are statistically significant or if, on the contrary, they are merely eventual, we previously verified their applicability through the assumptions of normality and homoscedasticity of each of the data sets, using the ANOVA test (FISHER, 1918). It was possible to observe that for both the amounts of revenue and expenditure, as well as for the percentages, the $\mathrm{p}$ value observed in the ANOVA test was equal to 0.000 (i.e. less than 0.050), implying the rejection of the null hypotheses and the acceptance of the alternative hypotheses, according to which the average values of revenue and expenditure, and the average values of the percentages are not all equal.

The conclusion is that there was some measure of budgetary consolidation, but this must have been due to other factors, such as the economic climate, since there is no direct relationship between revenue, fiscal expenditure and budgetary consolidation in any of the periods studied. 


\section{REFERENCES}

Afonso, A., Jalles, J. (2012). Measuring the success of fiscal consolidations. Applied Financial Economics 22, 1053-1061.

Aramayo, M. (1997). Beneficios y minoraciones en derecho tributario. Madrid: Marcial Pors.

Banco de Portugal (2008). Relatório Anual 2008. Banco de Portugal. Retrieved from https://www.bportugal.pt/sites/default/files/anexos/documentos-relacionados/ft0061_d090602_h103733-0061-cam-200812-cai.pdf.

Bell, E., Bryman, A. (2004). Social research methods. Oxford, Oxford University Press.

Bell, J. (2004). Como realizar um projecto de investigação: Um guia para a pesquisa em ciências sociais e da educação. Lisboa: Gradiva.

Bilhim, J. (2016). Políticas públicas e agenda política. Valorizar a tradição: Orações de sapiência do ISCSP. Lisboa: Instituto Superior de Ciências Sociais e Políticas. Brixi, H., Swift, Z., Valenduc, C. (2004). Tax expenditures: general concept, measurement, and overview of country practices. In Brixi, H., Swift, Z., Valenduc, C. (Eds.). Tax expenditures - Shedding light on government spending through the tax system (pp. 1-18). Washington, D.C.: The World Bank.

Cabral, N., Martins, G. (2014). Finanças públicas e direito financeiro - Noções fundamentais. Lisboa: Associação Académica da Faculdade de Direito de Lisboa.

Caldas, R. (2008). Políticas públicas: Conceitos e práticas. Belo Horizonte: Casa de Editoração e Arte, Ltda.

Carmo, H., Malheiro, M. (2008). Metodologia de investigação, guia para autoaprendizagem. Lisboa: Universidade Aberta.

Catarino, J. (2017). Teoria fiscal. In Catarino, J., Guimarães, V. (Eds.). Lições de fiscalidade (5. ${ }^{a}$ edição). Coimbra: Almedina.

Catarino, J. (2020). Finanças públicas e direito financeiro (5 $5^{a}$ edição). Coimbra: Almedina.

Catarino, J., Fonseca, J. (2013). Sustentabilidade financeira e orçamental em contexto de crise global numa Europa de moeda única. Sequência, Florianópolis 34(67), 21-51. 
Catarino, J., Teixeira, M. (2016). Resiliência da progressividade, da capacidade contributiva e da redistribuição de renda na tributação das pessoas físicas em época de crise - um estudo objetivado na crise financeira portuguesa. Revista Direito GV 12(3), 734-727.

Devries, P., Guajardo, J., Pescatori, A., Leigh, D. (2016). A new action-based dataset of fiscal consolidation. Retrieved from https://www.imf.org/en/Publications/WP/Issues/2016/12/31/A-New-Action-Based-Dataset-of-Fiscal-Consolidation-24892.

Dye, T. (1972). Understanding public policy. Englewood Cliffs: Prentice Hall. Ende, L., Haberham, A., Boogert, K. (2004). Tax expenditures in the Netherlands. In Brixi, H., Swift, Z., Valenduc, C. (Eds.). Tax expenditures - Shedding light on government spending through the tax system. Washington, D.C.: The World Bank.

European Commission. (2007). Public Finances in EMU - 2007. Brussels: European Union.

European Union (2012a). The economic adjustment programme for Portugal fourth review - Spring 2012 (Occasional Papers 111, julho 2012). Retrieved from https://ec.europa.eu/economy_finance/publications/occasional_paper/2012/ pdf/ocp111_en.pdf.

European Union (2012b). The economic adjustment programme for Portugal fifth review - Summer 2012 (Occasional Papers 117, outubro 2012). Retrieved from https://ec.europa.eu/economy_finance/publications/occasional_paper/2012/pdf/ocp117_en.pdf.

European Union (2012c). The economic adjustment programme for Portugal sixth review - Autumn 2012 (Occasional Papers 124, dezembro 2012). Retrieved from https://ec.europa.eu/economy_finance/publications/occasional_paper/2012/pdf/ocp124_en.pdf.

Eurostat (2013). Taxations trends in the European Union. Retrieved from https:// ec.europa.eu/taxation_customs/sites/taxation/files/resources/documents/ taxation/gen_info/economic_analysis/tax_structures/2013/report.pdf.

Fadigas, L. (2015). Urbanismo e território - As políticas públicas. Lisboa: Edições Silabo.

Ferreira, R. (2011). Política fiscal. Revista de Finanças Públicas e Direito Fiscal, Lisboa 2(4), 36-46. 
Fisher, R. (1918). The Correlation Between Relatives on the Supposition of Mendelian Inheritance. Philosophical Transactions of the Royal Society of Edinburgh, 52(2), 399-433.

Garcia, L. (2002). Medidas fiscales para el desarrollo económico. XXI Jornadas Latinoamericanas de Derecho. Retrieved from http://www.uckmar.net/ILADT/tema1/venezuela/Palacios.htm.

Giuliodori, M., Beetsma, R., Cimadomo, J., Furtuna, O. (2015). The confidence effects of fiscal consolidations. Great Britain: Centre for Economic Policy Research.

Gomes, N. (1991). Teoria geral dos benefícios fiscais. Lisboa: Direção-Geral de Contribuições e Impostos, Ministério das Finanças.

Howard, C. (1995). Testing the tools approach: tax expenditures versus direct expenditures. Public Administration Review 55(5), 439-447.

Hughes, O. (1994). Public management and administration: An introduction. London: Palgrave.

International Monetary Fund (2007). Manual on fiscal transparency. Washington D.C.: International Monetary Fund.

International Monetary Fund (2012a). Portugal: Third review under the extended arrangement and request for waiver of applicability of end-March performance criteria. Retrieved from https://www.imf.org/en/Publications/CR/ Issues/2016/12/31/Portugal-Third-Review-Under-the-Extended-Arrangement-and-Request-for-Waiver-of-Applicability-25826.

International Monetary Fund (2012b). Portugal: Fourth review under the extended arrangement and request for a waiver of applicability of end-June performance criteria. Retrieved from https://www.imf.org/external/pubs/ft/scr/2012/ cr12179.pdf.

Knoepfel, P., Larrue, C., Varone, F., Hill, M. (2007). Public policy analysis. Bristol: Policy Press.

Kraan, D. (2004). Off-budget and tax expenditures. OECD Journal on Budgeting 4(1), 121-142.

Lasswell, H., Kaplan, A. (1950). Power and society: A framework for political inquiry. London: Routledge.

Lemieux, V. (1995). L'étude des politiques publiques: les acteurs et leur pouvoir. Sainte-Foy-Tarentaise: Les Presses de l’Université Laval Dyu. 
Martins, G. (2004). A despesa fiscal e o orçamento do Estado no ordenamento jurídico português. Coimbra: Almedina.

Martins, G. (2014). Consolidação orçamental e política financeira. Coimbra: Almedina.

Mcdaniel, P., Surrey, S. (1985). Tax expenditures. Cambridge: Harvard University Press.

Melazzo, E. (2010). Problematizando o conceito de políticas públicas: desafios à análise e à prática do planejamento e da gestão. Tópos 4(2), 9-32.

Mény, Y., Thoenig, J. (1989). Politiques publiques. Paris: Presses Universitaires de France

Ministério das Finanças (1998). Reavaliação dos benefícios fiscais. Lisboa: DGCI.

Ministério das Finanças (2005). Reavaliação dos benefícios fiscais. Lisboa: DGCI.

Ministério das Finanças (2011). Programa de assistência económica e financeira EU/FMI. Lisboa: Banco de Portugal.

Ministério das Finanças (2011). Programa de estabilidade e crescimento 2011-2014. Retrieved from https://www.parlamento.pt/orcamentoestado/Documents/ pec/21032011-PEC2011_2014.pdf.

Ministério das Finanças (2012). Conta geral do Estado 2012. Retrieved from https://www.dgo.pt/politicaorcamental/ContaGeraldoEstado/2012/ CGE_2012_vol1.pdf.

Ministério das Finanças (2013). Conta geral do Estado 2013. Retrieved from https://www.dgo.pt/politicaorcamental/ContaGeraldoEstado/2013/ CGE_2013_vol1.pdf.

Ministério das Finanças (2014). Documento de estratégia orçamental 20142018. Retrieved from https://www.dgo.gov.pt/politicaorcamental/Documents/DEO_2014-2018.pdf.

Ministério das Finanças (2014). Relatório da despesa fiscal 2014. Retrieved from https://www.dgo.pt/politicaorcamental/OrcamentodeEstado/2014/Proposta\%20do\%20Or\%C3\%A7amento/Documentos\%20do\%20OE/Rel-2014.pdf. Ministério das Finanças (2016). Relatório do orçamento do Estado para 2016. Retrieved from https://www.portugal.gov.pt/download-ficheiros/ ficheiro.aspx?v=6b688a13-e7c9-4f1f-9fc7-5f90b0f39925. 
Ministério das Finanças (2017). Programa de estabilidade 2017-2021. Retrieved from https://www.portugal.gov.pt/pt/gc21/governo/programa/ programa-de-estabilidade.aspx.

Molnár, M. (2012). Fiscal consolidation: what factors determine the success of consolidation efforts? OECD Journal: Economic Studies 2012(1), 123-149.

Muller, P. (1990). Les Politiques Publiques. Paris. Presses Universitaires de France.

Nakamura, T., Singleton, R. (2016). An international comparison of tax base erosion due to tax expenditures. International Journal of Business Accounting and Finance 10(1), 54-68.

Nohlen, D. (2008). Conceptos y contexto: en torno al desarollo de la comparación en ciencia política. Barcelona: Institut de Ciencies Politiques i Socials.

OECD (1996). Tax expenditure recent experiences. Paris: OECD Publications. OECD (2010). Tax expenditures in OECD Countries. Paris: OECD Publications. OECD (2011). Restoring public finances. OECD Journal on Budgeting (Special Issue), 2011(2).

OECD (2013a). Government at a glance 2013. Paris: OECD Publications.

OECD (2013b). Portugal: reforming the State to promote growth. Paris: OECD Publications.

OECD (2014). Portugal: deepening structural reform to support growth and competitiveness. Paris: OECD Publications.

Pereira, P., Santos, J., Arcanjo, M., Afonso, A. (2012). Economia e finanças públicas. Lisboa: Escolar Editora.

Poterba, J. (2011). Introduction: economic analysis of tax expenditures. National Tax Journal 64(2), 451-458.

Saraiva, E. (2006). Introdução à teoria política pública. In Saraiva, E., Ferrarezi, E. (Org.). Políticas Públicas (Volume 1). Brasília. ENAP, 2006.

Sunley, E. (2004). Tax expenditures in the United States: experience and pratice. In Brixi, H., Swift, Z., Valenduc, C. (Eds.). Tax expenditures - Shedding light on government spending through the tax system. Washington, D.C.: The World Bank.

Tribunal de Contas (2012). Parecer sobre a conta geral do Estado ano económico de 2012. Retrieved from https://erario.tcontas.pt/pt/actos/ parecer-cge/2012/parecer-cge-2012.shtm. 
Tribunal de Contas (2014). Auditoria à quantificação da despesa fiscal (Relatório n. ${ }^{\circ}$ 19/2014). Retrieved from https://www.tcontas.pt/pt-pt/ProdutosTC/Relatorios/RelatoriosAuditoria/Documents/2014/rel019-2014-2s.pdf. Yin, R. (2009). Case study research: Design and methods (Fourth Edition). London: Sage.

\section{JOÃO RICARDO CATARINO}

Integrated Researcher at the Center for Administration and Public Policy (Research Center registered at the Foundation for Science and Technology (FCT), Institute of Social and Political Sciences, University of Lisbon. PhD in Social Sciences in the specialty of Public Administration at the University of Lisbon. Full Professor of Taxation, Public Finance and Financial Law at the Institute of Social and Political Sciences (ISCSP), University of Lisbon and at the Institute of Accounting and Administration of Lisbon (ISCAL), Polytechnic Institute of Lisbon. Member of several Portuguese Tax System Reform Commissions (IVA (1986); IRS, IRC (1989), Property Taxes (2003/2004) and IRS - Personal Income Tax (2014). Judge in arbitration Tax at the Administrative Arbitration Center (CAAD).

Professional address: Universidade de Lisboa, Instituto Superior de Ciências Sociais e Políticas, Centro de Administração e Políticas Públicas. Campus Universitário, Alto da Ajuda, Rua Almerindo Lessa, 1300-663, Lisboa, Portugal.

ORCID ID: https://orcid.org/0000-0001-9372-083X

E-MAIL: jcatarino@iscsp.ulisboa.pt

\section{RUI MIGUEL ALCARIO SALVADOR}

Master's Degree in Public Administration (MPA), Institute of Social and Political Sciences, University of Lisbon (ULisboa); Postgraduate Degree in Accounting, Public Finance and Budget Management 
at Instituto Superior de Economia e Gestão (ISEG) / Universidade Técnica de Lisboa (UTL); Degree in Management from Universidade Autónoma de Lisboa (UAL). Performance of public functions in various bodies of the Portuguese Public Administration: Directorate General of Contributions and Taxes (DGCI), currently AT - Tax and Customs Authority, Directorate General of Budget (DGO), Inspectorate General of Environment and Spatial Planning (IGAOT) - holding the position of middle manager - and the Portuguese Court of Auditors.

Professional address: Instituto Superior de Ciências Sociais e Políticas, Rua Almerindo Lessa - 1300-663 Lisboa, Portugal.

ORCID ID: https://orcid.org/0000-0002-6255-3116

E-MAIL: ruisalvador74@gmail.com

\section{RICARDO DE MORAES E SOARES}

Associate Researcher at the Administration Center and Public Policies (Research center registered at the Foundation for the Science and Technology (FCT)), Higher Institute of Social and Political Sciences, University of Lisbon. PhD in Public Administration in the specialty of Public Policies. Assistant Professor of Public Accounting, Management and Public Finance at the Institute of Social and Political Sciences (ISCSP), University of Lisbon.

Professional address: Universidade de Lisboa, Instituto Superior de Ciências Sociais e Políticas, Centro de Administração e Políticas Públicas. Polo Universitário, Alto da Ajuda, Rua Almerindo Lessa, 1300-663, Lisboa, Portugal.

ORCID: https://orcid.org/0000-0002-7840-7340

E-MAIL: rsoares@iscsp.ulisboa.pt

Received: 2021.08 .06

Accepted: 2021.10.04 


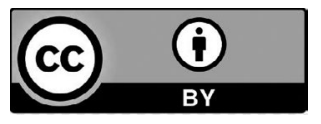

This work is licensed under a Creative Commons Attribution 4.0 International License.

LICENSE TO USE: Authors grant Sequência Journal exclusive rights of first publication, and the work is licensed under the Creative Commons Attribution 4.0 International License. The license authorizes third parties to remix, adapt, and/ or create from the published work, indicating credit to the original work and its initial publication. The authors are allowed to enter into additional separate agreements, with non-exclusive distribution of the version published in Sequência Journal, indicating, in any case, authorship and initial publication in this journal. 